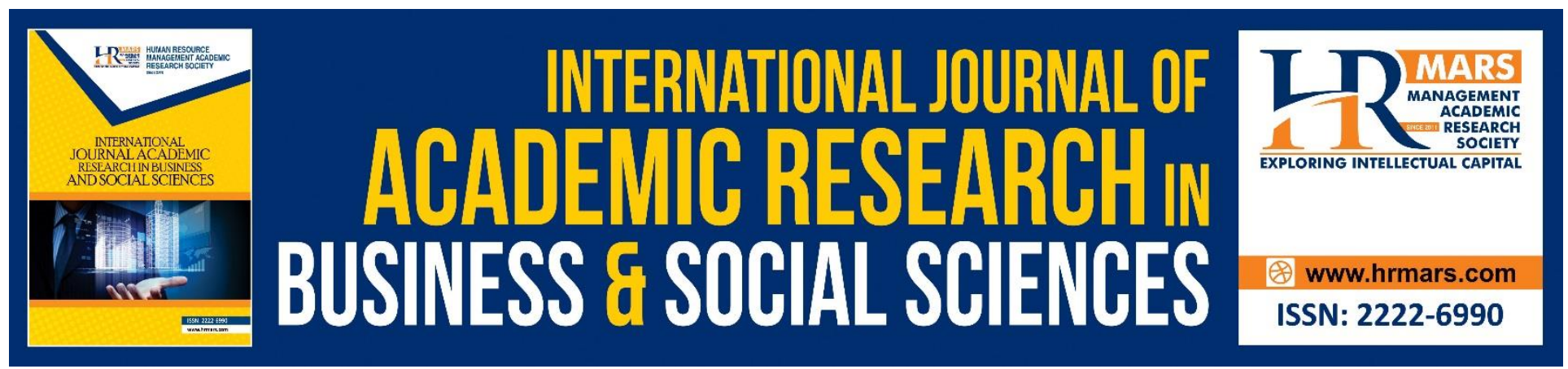

\title{
Human Development Based on Spiritual Values and Its Relevance to the Concept of Akhlaq in Islam
}

Noor Shakirah Mat Akhir, Norshabiha Ibrahim

To Link this Article: http://dx.doi.org/10.6007/IJARBSS/v10-i8/7539

DOI:10.6007/IJARBSS/v10-i8/7539

Received: 16 May 2020, Revised: 18 June 2020, Accepted: 21 July 2020

Published Online: 27 August 2020

In-Text Citation: (Akhir, Ibrahim, 2020)

To Cite this Article: Akhir, N. S. M., \& Ibrahim, N. (2020). Human Development Based on Spiritual Values and Its Relevance to The Concept of Akhlaq in Islam. International Journal of Academic Research in Business and Social Sciences. 10(8), 295-304.

Copyright: @ 2020 The Author(s)

Published by Human Resource Management Academic Research Society (www.hrmars.com)

This article is published under the Creative Commons Attribution (CC BY 4.0) license. Anyone may reproduce, distribute, translate and create derivative works of this article (for both commercial and non-commercial purposes), subject to full attribution to the original publication and authors. The full terms of this license may be seen

at: http://creativecommons.org/licences/by/4.0/legalcode

Vol. 10, No. 8, 2020, Pg. $295-304$

http://hrmars.com/index.php/pages/detail/IJARBSS

JOURNAL HOMEPAGE

Full Terms \& Conditions of access and use can be found at http://hrmars.com/index.php/pages/detail/publication-ethics 


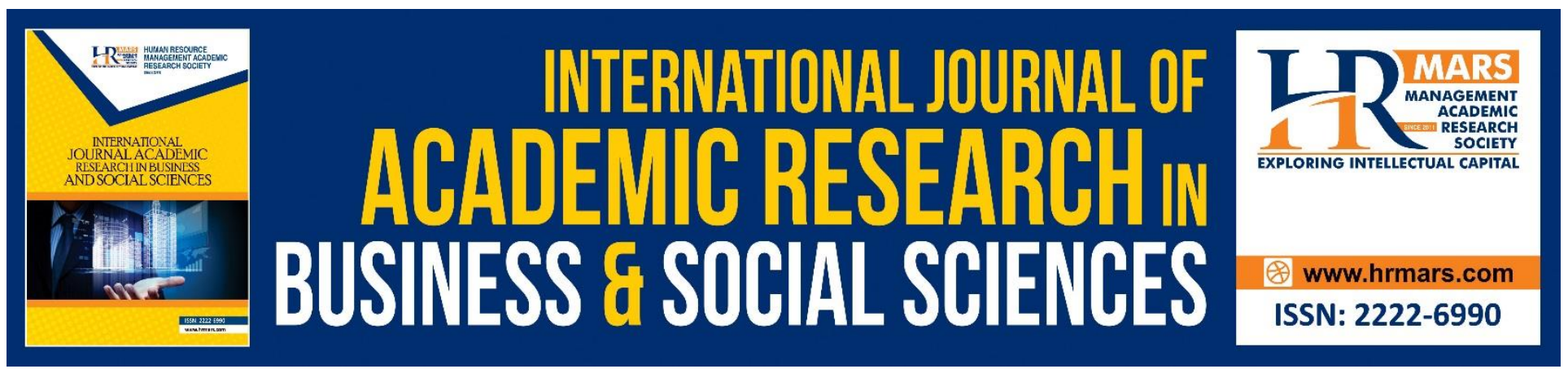

\title{
Human Development Based on Spiritual Values and Its Relevance to the Concept of Akhlaq in Islam
}

\author{
Noor Shakirah Mat Akhir, Norshabiha Ibrahim \\ School of Humanities, Universiti Sains Malaysia, 11800, Pulau Pinang, Malaysia
}

\begin{abstract}
The ever-changing world should not compromise on the humanity values of a nation. The same should apply to religious values; far from it being side-lined, it should in fact remain throughout the ages a bastion of guidance for humankind in their development and resources. Religion backed spiritual values undeniably are the ultimate basis for guiding principle in the development of humans in particular and in their lives in general. Spiritual values are closely related to the aspect of morality as is the case with Islam where Islamic concept of akhlaq involves internal aspects. Islam prioritizes akhlaq above all aspects of life for which guidelines had been set. The concept of akhlaq in Islam centres around the faith of oneness of Allah (aqidah tawhid) which must begin from within oneself. Hence, spiritual values need to first be inculcated in oneself in order for them (the values) to be rendered into practice to achieve the height of human development. This article attempts to discuss the spiritual prerequisites needed to be present in the human development process, which by itself is the primary capital in human resources. The purpose of which is to perpetuate the sustainability of a particular nation.
\end{abstract}

Keywords: Human, Development, Akhlaq, Moral, Spiritual.

\section{Introduction}

Spiritual values in the context of modern life is often given the backseat. The tendency towards material values has resulted in moral decline in society. The various social ills amongst the Malaysian society, in particular the adolescence, to date is a cause for great concern. Statistic by the Malaysia Crime Prevention Foundation (MCPF) shows the crime index in 2017 recorded a staggering number of 1722 students-offenders and subsequent year the index decreased to 1286 students that were detained. This is a significant number in cases of misconduct among adolescents (Harian, 2019). This alarming scenario may thwart the human development process, therefore there is empirical to return to the understanding, practising, and appreciating of the spiritual values which are not only very much in line with the human nature (creation?) it is also based on monotheistic faith.

Faith

Islam is a monotheistic religion. Tawhid means recognition of oneness of Allah. The first confession in the shahadah is that there is no god to be worshipped except Allah. This Tawhid concept is 
INTERNATIONAL JOURNAL OF ACADEMIC RESEARCH IN BUSINESS AND SOCIAL SCIENCES

Vol. 10, No. 8, 2020, E-ISSN: 2222-6990 @ 2020 HRMARS

instrumental in the development of the soul and must be the core of all deeds and behaviours of all Muslims, be it in the thinking process, lifestyle and behavior. By virtue of verse 162-163 of chapter al-An'am, Allah says:

Say "Indeed my prayers, my rites of sacrifice, my living and my dying are for Allah, Lord of the worlds. No partner has He. And this I have been commanded, and I am the first to submit."

Islam presents an outlook on life through the concept of tawhid, i.e. belief in the existence of Allah Almighty. By relying on this principle, humans are guided by god on how to live their lives. From the same basis too, four aspects could be derived by which Muslims needed to abide. Namely, relationship with Allah, relationship with humans, relationship with nature and lastly relationship with oneself. The execution of these four aspects is essential upon each individual in their respective lives and will determine how one acts in this world.

\section{The Creation of Human}

The creation of human from the perspective of Islam can be explained from two main angles, namely spiritual and physical. The perfection and the balance of human development of an individual need to adhere to these two aspects. The factual existence of humans in Islam owes its authority on alQuran and the hadith both of which represent the two main sources of knowledge in Islam. The Quran states that the spiritual element i.e the soul of human is not easily comprehensible nor deduced by facts and figures but the existence of it needs to be acknowledged nonetheless. Allah says in chapter al-Hijr, verse 29 as follows:

"And when I have made it complete, and I have breathed into it the spirit of (My creation), then fall down to it in prostration."

But the reality of the soul/spirit is that the knowledge about them belongs to Allah alone; as goes the following verse:

"And they ask you about the spirit. Say: the spirit is the business of my Lord, and you are not given knowledge except a little." (al-Isra':85)

There a several other Quranic verses that speak about the physical aspect of human creation. They are from water; al-Furqan: 54, from the soil; al-Anbiya ': 30, from the essence of the soil; al-Saffat: 11 , from the soil that is hot and smelly; al-Hijr: 28, from hard soil like pottery; al-Rahman: 14 and from earthly soil; al-Najm: 32.

\section{Man as Caliph}

The discourse of human development must also involve the role of human as a creature of Allah. Humans assume the role of caliphs of Allah in the face of the earth. Literally, Caliph means the supreme leader (Ibn Manzur, 1999, p. 182-183. See also al-Fairuzabadi, 1993, p. 1044). Allah says:

"Remember when your Lord said to the angels: 'verily I want to make a caliph on earth', they said: 'why do you want to make (caliph) on earth a person who will do damage in it and shed blood, when we always glorify with praise and sanctify you?'

Allah said: 'Verily I know that which you do not know" (al-Baqarah:30) 
INTERNATIONAL JOURNAL OF ACADEMIC RESEARCH IN BUSINESS AND SOCIAL SCIENCES Vol. 10, No. 8, 2020, E-ISSN: 2222-6990 @ 2020 HRMARS

Corresponding to the connotation of the word caliph, humans are indeed the leaders of this world. As leaders, human beings are endowed with intellects which is denied in other creatures, hence, human beings are the best of creations. Allah says in Chapter al-Tin:4:

"Indeed we have created man in the best form"

A human who comes with two coexisting elements; physical and spiritual has to bear two simultaneous responsibilities. Responsibility to the spiritual demands and the needs of the physical body must be balanced. What it means by balance is prioritising the spiritual body without neglecting the physical one.

Islam advocates spiritual perfection as the ultimate goal because spirituality is the essence of human beings. The culmination of spirituality is unattainable if the needs of the physical body is neglected. This is simply the nature of the creation of human being itself (Tabbarah, 1992).

\section{The Concept of Akhlaq in Islam}

The issue of akhlaq occupies a prominent place in Islam. Its scope of akhlaq is vast involving relationship with the creator, amongst humans, other creatures and even with this world. The concept of akhlaq is closely related to the development of human. Akhlaq mahmudah (good behaviour) of righteous individuals are indeed the capital for development in all aspects.

Akhlaq refers to soul situations from which action ensues without involving thinking process. According to Ibn Miskawayh (1961:36), akhlaq could also be the product of souls nurtured via custom and self-discipline. It might begin with contemplation and thoughts, but with consistent practice it gradually turns into one' s habit, routine and akhlaq. To sum up, akhlaq refers to values that permeate the spiritual or soul of an individual from which actions are generated effortlessly without the needs for thoughts and considerations. Therefore, noble akhlaq are the product of spiritual exercise that further discussions will be presented in the concept of tazkiyah al-nafs.

All human behaviours and conscious actions are the result of their internal situation which shapes how one sees and understands something. An internal situation refers to a person's nafs situation. Nafs will push people towards good or bad depending on the level of nafs' compliance with Islamic teachings.

Therefore, akhlaq or al-khuluq is a conviction that permeates into spiritual/soul, responsible for conducts that require no contemplation, consideration or thinking. If what ensues from spiritual situation is good and praiseworthy according to sound mind and sharia, then the conduct or behaviour is deemed as virtuous akhlaq (mahmudah), and on the contrary, it is called reprehensible akhlaq (mazmumah). The word al-khuluq which means internal situation and al-khalq which means physical form are two coexisting words often applied together. If for example one is seen to be displaying good conducts, he as a matter of fact is good from the inside and out. This is particularly so because each individual is comprised of physical body which is visible to the naked eyes as well as spiritual body which takes no form, nor visible in plain sight. Both bodies possess characteristics that would propel good or bad conducts (Al-Ghazali, 1964). In this regard, al-khuluq which represents the inner nature is not the same as al-fi'l (deeds). This is due to the fact that what a person does, does not necessarily reflect the state of his soul (Al-Ghazali, 1994). For example, a poor person is unable to donate even though internally he knows that generosity is encouraged. Similarly, a wealthy donor may not sincerely donate but for ulterior motives. 
INTERNATIONAL JOURNAL OF ACADEMIC RESEARCH IN BUSINESS AND SOCIAL SCIENCES Vol. 10, No. 8, 2020, E-ISSN: 2222-6990 @ 2020 HRMARS

\section{The Concept of Life and Akhlaq in Islam}

The universe, according to the perspective of Islam is a creation of Allah. He is the ultimate sole administrator, commander, preserver and the universe functions under His directions. Allah is AllKnowing and Al-Powerful over all creatures. He is pure from all shortcomings, mistakes and weaknesses and any other negative traits. His divinity is free from injustice and bias.

Humans are his creation and his subjects. They are put on earth to worship and obey Him. The purpose of human's life is to live in piety and obedience to Allah. It is He (not human) who has the right to determine the manner in which worship is performed and any other forms of obedience.

Throughout the ages, Allah sent prophets to set examples and teach guidance to mankind; dispensing revelations through them that were enshrined in scriptures. It is human's duty to ensure that his life is tethered around Allah's commands and His divine law.

Humans are responsible unto Allah upon their deeds and they will be accounted for in the hereafter. The short span of life in this world is ample opportunity for them to make preparations to deal with greater tests. Humans will be judged fairly, not only on the actions and the consequences thereof in this world (from the smallest particles to the highest of mountains) but also with respect to their thoughts and feelings as well as intentions.

Awareness that this life on earth is only temporary and the eternal afterlife awaits makes a person to be attentive to his responsibility in this world. The awareness helps one to direct his actions to be in line with defined moral guidelines prescribed by religion. This is what al-Ghazali advises in his discussion on nafs, that individuals often ponder upon his creation, the purpose of his life in the world and what will happen after this worldly life (Al-Ghazali, 1976).

Worship also plays an important role in the formation of morality; after all, in Islam humans are created to worship Allah. The concept of worship in Islam is broad. It includes specific and general rituals each of which, whether obligatory or mere supplications are all aiming at achieving the ultimate goal of every Islamic teaching, which is building morality uprightness. This is clearly seen from the internal and external effects of each particular worship as further elaborated in Chapter alAnkabut, verse 45:

"indeed prayer prevents from abominable and evil deeds"

Literally, prayer means praying for good. From the Islamic point of view, prayer means utterance and movements that begins from takbir and ends with salam with certain other conditions (Abd Rahman al-Jaziri, 1986). Nonetheless, prayer is not only ritualistic movements but it involves internal (spiritual) aspects of a person. The perfection of prayer which combines both physical and spiritual aspects will ensure that the prayer is able to prevent a person from committing wrongs or evil deeds. The same goes for other specific acts of worship that produce spiritual and physical effects unto individuals who perform them correctly. ${ }^{i}$

In addition to specific worship, Muslim individuals need from time to time allocate time for activities which could strengthen their spirituality; after all, human beings are made up of spiritual and physical elements. If the human body needs food, so does his spiritual body only this time it needs to be nourished with spiritual practices. Faith needs to be nurtured as goes the hadith of the Prophet (pbuh), narrated by Ahmad:

"Always renew your faith. The companions asked 'How do we renew our faiths, O' messenger of Allah? He said: 'chant the words of La Ilah illa Allah". 
INTERNATIONAL JOURNAL OF ACADEMIC RESEARCH IN BUSINESS AND SOCIAL SCIENCES Vol. 10, No. 8, 2020, E-ISSN: 2222-6990 @ 2020 HRMARS

Apart from incantation, worship also plays a role in strengthening faith as mentioned in the al-Quran, among others: Chapter al-Muzammil. This chapter illustrates the needs to perform supplications prayers at night and other spiritual practices such as reciting the Quran (Muhammad 'Ali al-Sabuni, 2001).

\section{Human Development Through Tazkiyah al-Nafs}

In the process of producing solid human development, the spiritual aspect of a person needs to be driven by beneficial knowledge. This (knowledge input) process indirectly makes a soul purifying practice an important scheme because only with a clean soul that knowledge could penetrate and be appreciated. From the Islamic perspective, this process of purification of the soul is termed as the process of Tazkiyah al-nafs.

In line with the nature of human creation, the reality of human development must also comply with the same aspects of human creation, that is the spiritual element. In doing so, the aspect of human spiritual development can be refined through the method of tazkiyah al-nafs as encouraged by Islam. Tazkiyah literally means cleansing. Al-nafs on the other hand means the essence of the human self and it can also refer to the strength of anger and lust inherent in human. Technically, tazkiyah al-nafs refers to the process of purification of the human self from evil and lustful desires and replace it with permissible desires that are on the right path in accordance with the requirements of sharia.

The process of Tazkiyah al-nafs contains two main dimensions, namely al-takhalli and al-tahalli. Altakhalli refers to the process of purifying oneself from reprehensible attributes while al-tahalli is the process of adorning oneself with noble and praiseworthy attributes. Thus it can be understood that in the process of Tazkiyah al-nafs, the effort does not stop at freeing oneself from the attributes of mazmumah but it needs to be proceeded with inculcation of mahmudah values.

This tazkiyah al-nafs process is a method to improve morality based on Islamic teaching. It is placed high up a pedestal in a prophetic mission as portrayed in al-Quran in the following verses:

" $O$ ' our Lord, send to them a Messenger from among them, who will recite to them Your verses, and teach them the Book (Al Quran) and wisdom (As-Sunnah) and purify them. Lo! Thou, only Thou, art the Mighty, the Wise." (al-Baqarah:129),

"As (We have perfected our favours to you) We have sent you a Messenger among you who recited our verses to you and purified you and taught you the Book and the Wisdom, and taught you what you did not know." (Al-Baqarah: 151)

"He is the One who sent to the illiterate people a Messenger among them, who recited His verses to them, purified them and taught them the Book and wisdom (As Sunnah). And verily! they were before, in utter error." (Al-Jumuah: 2).

Clearly, the above verses illustrate that one of the main tasks of the messenger is to purify the souls of mankind. The prophet (pbuh) also said:

"Indeed I was sent to perfect noble morals" (Musnad Ahmad).

The perfection of good morality is hence the core cause in the mission of prophethood. On another note, there is no denying that good morals will only result from clean souls which is attainable from continuous process of tazkiyah al-nafs. Individuals with high morality will certainly enjoy success in 
INTERNATIONAL JOURNAL OF ACADEMIC RESEARCH IN BUSINESS AND SOCIAL SCIENCES Vol. 10, No. 8, 2020, E-ISSN: 2222-6990 @ 2020 HRMARS

this world as well as in the hereafter as evidenced by the following Quranic verse 7-10 of chapter alShams.

"And the soul and its perfection (creation), So Allah inspired the soul (the path) of wickedness and piety. Blessed is he who purifies the soul, and verily he who defiles it will lose."

There are certain mechanisms in the process of implementation of tazkiyah al-nafs. It has to include both scopes i,e. taklif ilahi which is to perform the commands and leave the forbidden. The taklif in the form of injunction comprises of all obligatory and supplications and other noble practices. Taklif in the form of prohibition on the other hand, involves omitting from practices prohibited by the sharia. Both forms of taklifs need to be performed to one's level best to guarantee the effect of high morality being formed within the individual so striving.

The al-Quran mentions three categories of nafs, namely nafs al-mutmainnah, nafs al-lawwamah and nafs al-ammarah. This division does not mean that each human has three different souls. This is why, in Arabic it is not referred to as nufus or anfus (which is the plural noun of nafs) when referring to the soul of any specific individual; unless the sentence refers to souls in general as illustrated in chapter al-Takwir, verse 7; Allah says:

"... and when the souls are reunited with the body"

Nafs al-mutmainnah is a calm and peaceful soul with the pleasure and love of Allah, which is contented with its fate and destiny (qada' and qadar), a soul which utters and remembers Him with longing, one which feels nearness to Allah and truly believes in Allah's promises to His servants. This kind of soul is what is described at death as follows:

"O silent soul! Return to your Lord in peace and contentment, enter among My servants (whom I am pleased with) and enter My Paradise" (al-Fajr: 28).

Nafs al-Lawwamah on the other hand is a soul that often do self-criticizing and regretting the limitations in performing actions of obedience or restricted from performing other virtuous acts or due to committing any wrongs, offense or bad things.

On the contrary, nafs al-ammarah is the soul that always pushes a person towards mischief and evil (ammarah bi al-su') and always calls human to fulfil desires of self and lust which leads to misguidance, wickedness, falsehood and violation.

Thus in each individual, there are three nafs or lusts with different functions and respective characteristic: ammarah, lawwamah and mutmainnah. What this means is that there are three diverse energies in human beings that are always competing to dominate the other two. What needs to be understood is that nafs (lust) is not prevalently evil or bad. Islam does not demand that nafs be eliminated or killed right-off because nafs has its importance in human life without which, there could be no progress and prosperity in the world. "i Due to this, Allah made humans as his caliphs on earth and not the angels who are devoid of nafs. What Islam advocates is the control of nafs so that it is right on track, not its removal. For example, human beings need to have a desire to eat but it should not be in excess, instead just enough to enable them to perform acts of worship to Allah the Almighty and not to overdo it to the extent of harming one's health. Humans are also endowed with various spiritual potentials such as desire to love and to be loved, sympathy, desire to look good and many more. These potentials need to be to be channelled towards positive direction. 
INTERNATIONAL JOURNAL OF ACADEMIC RESEARCH IN BUSINESS AND SOCIAL SCIENCES Vol. 10, No. 8, 2020, E-ISSN: 2222-6990 @ 2020 HRMARS

What is meant by soul nurturing through the process of tazkiyah al-nafs is an effort to eliminate the domination of nafs al-ammarah from one's heart and soul. In the event that nafs al-ammarah took control, then the human would succumb to despicable (mazmumah) deeds or conduct. Nafs allawwamah on the other hand, must always be improved to reach the next level. This is the reason of why tazkiyah al-nafs is of importance and needs to be employed because the balance of one individual's soul depends greatly on which category of nafs that is prevalent in his soul, thereby controls him.

\begin{tabular}{|l|l|l|l|l|}
\hline $\begin{array}{l}\text { The Level of balance } \\
\text { of the soul }\end{array}$ & Divine nature & Fierce nature & $\begin{array}{l}\text { Animalistic } \\
\text { nature }\end{array}$ & $\begin{array}{l}\text { Devilish } \\
\text { nature }\end{array}$ \\
\hline Nafs al-mutmainnah & Dominant & Submissive & Submissive & Submissive \\
\hline Nafs al-lawwamah & Half dominant & Half dominant & Half dominant & Half dominant \\
\hline Nafs al-ammarah & Submissive & Dominant & Dominant & Dominant \\
\hline
\end{tabular}

Source : (Akhir, 2019)

Figure 1: Level of dominance and submission of the main psychological elements of human according to situations of soul.

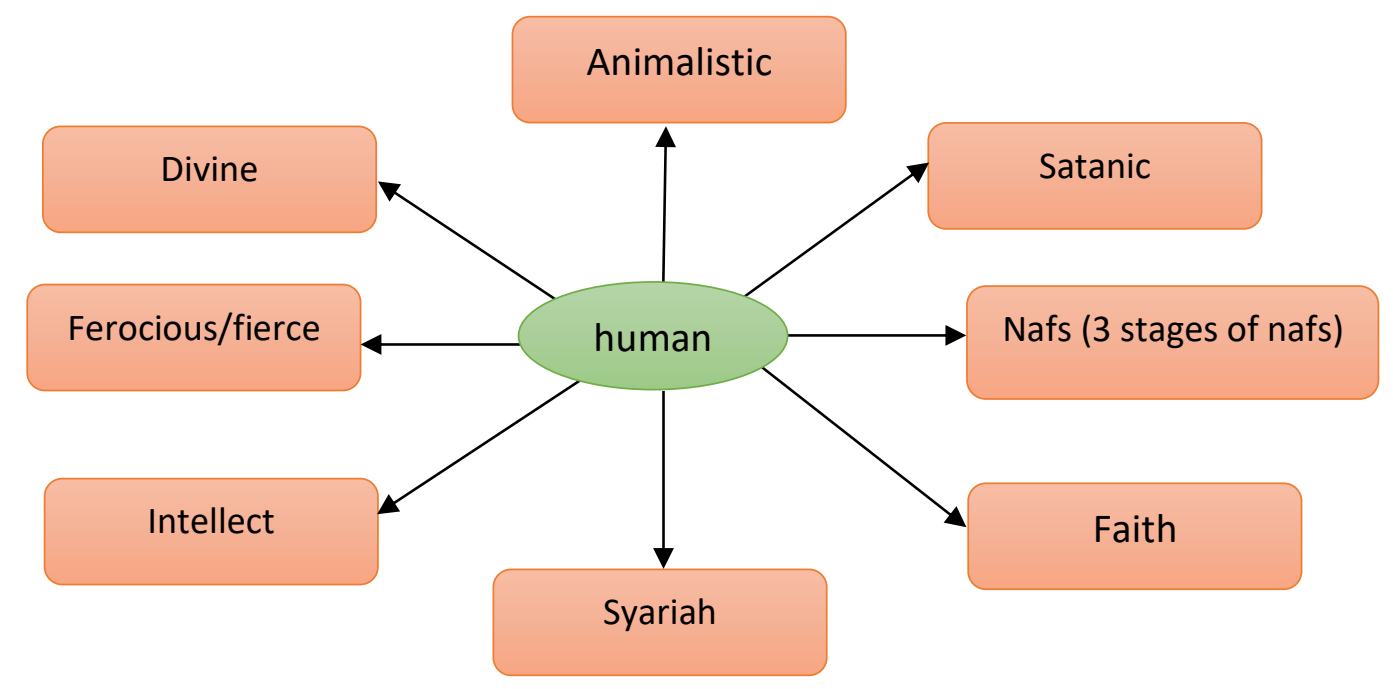

Figure 2: Dynamic Interaction of the Soul

Source : (Akhir, 2019)

\section{Human Development that Conforms to the Nature of the Creation of Human}

The issues of human capital are often heard in discourses. Human capital refers to the capital or any substance that can be derived from human to be utilized. In other words, human capital also denotes all that is sourced from humans. Therefore, human capital can also be equated with the term human resource. In the Malaysian context, human capital development is highly emphasized in the Ninth Malaysia Plan (9MP). The development of human capital is instrumental in ensuring the success of a particular country.

Development pertaining to human capital or human resources is not only substantial for the economic and material growth of a country but it is also significant in ensuring the sustainability of an individual's self-identity. In this regard, human capital development cannot be seen from the 
facets of physical and material per se, but it is even more important to be taken from the spiritual aspect of an individual.

Any investment venture of a country should not be restricted to material investment alone but it is wiser to include and in fact to give more emphasis on investments that involve the development of human capital. Human capital investment can be done in a variety of ways. In the effort to produce human beings with high capital, the firmness in faith, knowledge based and high morality are very much sought for. Hence pure soul and the development of human capital are intertwined. Sustainable human development must meet the two dimensions of an individual's needs. If a human being is made up of two elements, then his needs must also response to these two elements.

\section{Conclusion}

From the above discussions, it is clear that the spiritual aspect plays a major role in human development. The real human development does not revolve so much on the material facet but rather they are truly developed when their spiritual aspect is established. Only when coupled with this type of development can a nation be sustained and stay relevant. Islam offers an established and precise manual in the process of honing human development from its spiritual aspect, however they are not popular and definitely under-used in modern times as a method of akhlaq improvement. Tazkiyah al-nafs is a positive human capital mechanism that needs to be cultivated for the continuity of the nation.

This concept presented by Islam can be made a solid foundation in producing quality human beings. It can be applied to the Malaysian society according to the suitability of respective religious convictions. The quality human development needs to be viewed from the points of both physical as well as spiritual aspects with emphasis given to the spiritual face because it is the essence of the human self. The absence of any one aspect will result in imbalance in individual's life and thereby compromise human resources of a particular country.

The spiritual concept also needs to be formally incorporated into the education system. As listed in The Core Base of Human Capital Development Policy, it shows that education is the core medium in the process of human capital development. Human must be reminded to return to the teachings of their respective religion as it weighs heavily in contribution to high morals. Hence, morality and religion is inseparable. Religion is the strongest form of values, attitudes and behaviours. High morality certainly produces human capital of quality.

\section{Acknowledgements}

This study was funded by Fundamental Research Grant Scheme, Ministry of Education Malaysia number 203/PHUMANITI/6711590

\section{Corresponding Author}

Noor Shakirah Mat Akhir

School of Humanities

Universiti Sains Malaysia

11800, Pulau Pinang, Malaysia.

Email: shakirah@usm.my 
INTERNATIONAL JOURNAL OF ACADEMIC RESEARCH IN BUSINESS AND SOCIAL SCIENCES

Vol. 10, No. 8, 2020, E-ISSN: 2222-6990 @ 2020 HRMARS

\section{References}

Al-Quran al-Karim.

Al-Jaziri, A. R. (1986). Kitab al-Figh 'ala al-Madhahib al-Arba'ah, vol. 5, Beirut: Dar al-Kutub al'llmiyyah.

Akhir, N. S. (2008). Al Ghazali and His Theory of The Soul. Pulau Pinang: Universiti Sains Malaysia.

Akhir, N. S. M., \& Ibrahim, N. (2019). Analysis of Violent Act from the Islamic Spiritual Perspective. International Journal Academic Research Business and Social Sciences , 9(3), 1298 -1306.

Tabbarah, A. Abd. Al-F. (1992). Ruh Ad-Din Al-Islami. (Md. Akhir Hj. Yaacob,trans.). Kuala Lumpur: Bahagian Hal Ehwal Islam JPM.

Ahmad bin Abd Razak al-Dawish. (1996). Fatawa al-Lujnah al-Da'imah li al-Buhuth al-'Ilmiyyah wa alIfta', vol. 10, Riyadh: Ri'asah Idarah al-Buhuth al-'Ilmiyyah wa al-Ifta'.

Al-Ghazali. (1994). Ihya' 'Ulum al-Din, vol. 6, Damsyik: Dar al-Khayr.

Al-Ghazali. (1976). Kimiya-i Sa'adat, Tehran: Sherkate Sahami-ye Ketabhaye jibi in association with Franklin Book Programs, Inc. Partial English. (Claud Field, 1980 Trans of the Hindustani version.) The Alchemy of Happiness, London: Octagon Press.

Al-Ghazali. (1964). Mizan al-'Amal, (Sulayman Dunya, ed). Kaheran: Dar al-Maarif.

Ibn Hajar. (1993). Fath al-Bari bi Sharh Sahih al-Bukhari, (Abd al-Aziz bin Abd Allah bin Baz, ed). vol. 15, Beirut: Dar-Fikr.

Manzur, I. (1999). Lisan al-Arab, vol. 18, Beirut: Dar Al-Ihya'.

Miskawayh. (1961). Tahdhib al-Akhlaq. Beirut: Dar Maktabah al-Hayah.

Al-Sabuni, M. A. (2001). Safwat al-Tafasir, vol. 3, Beirut: al-Maktabah al-'Asriyyah.

Ibn Ya'kub al-Fairuzabadi, M. (1993). Al-Qamus al-Muhid, Beirut: Muassasah al-Risalat.

'This is also emphasised by al-Ghazali when he discussed secret of worship. See al-Ghazali, Ihya' Vol.1

ii Islam rejects the concept of self-denial, meditation and life in isolation. Islam encourages a spiritual concept that does not leave out the worldly aspects. This is in line with the teaching in al-Quran contained in Chapter al-Qasas, verse 77 where Allah reminds: "And seek what Allah has bestowed on you (happiness) of the Hereafter, and do not forget your share of (worldly pleasures) and do good (to others) as Allah has done good, to you, and do not You do mischief on the earth. Indeed, Allah does not like those who do mischief". In another verse, Allah says: "Then we accompanied behind them with our messengers and we accompanied (also) with Jesus son of Maryam; and we gave him the Gospel and we made in his heart those who followed him a sense of courtesy and love. And they invented rahbaniyyah when we did not oblige it to them but (they invented it themselves) to seek the pleasure of Allah, then they did not keep it with proper care. So We gave to those who believed among them their reward, and many of them were wrong-doers. (Al-Hadid: 27). A hadith records the prophet (pbuh) says: "There is no concept of priesthood in Islam". (Ahmad bin Abd Razak al-Dawish (1996), volume 6, p. 325) whereupon a priest can absolve sins upon the confession of the sinner. Although there are opinions that refute these words are hadith of the Prophet (pbuh), but it is acknowledged that the concept of priesthood has no place in Islam. Among those who deny these words as hadith is the view of Ibn Hajar al-'Asqalani. (Ibn Hajar (1993), volume 14, Chapter al-nikah, p. 293. 